DOI https://doi.org/10.30525/978-9934-588-80-8-1.8

\title{
АКТУАЛЬНІ ПИТАННЯ ПЕРИНАТАЛЬНОЇ ПСИХОЛОГЇ̈
}

\author{
Жданова I. B. \\ кандидат психологічних наук, дочент, \\ доиент кафедри соиіології та психології \\ Харківський наиіональний університет внутрішніх справ \\ Малєєва К. А. \\ аспірантка \\ Харківський національний університет внутрімніх справ \\ м. Харків, Украӥна
}

Перинатальна психологія - це молода галузь психологічної науки, яка в останні роки активно розвивається, завдяки працям таких відомих вчених як Гроф С., Добряков І. В., Брехман Г. І., Янус Л., Оден М. та інших. В Україні дослідження у цьому напрямку тільки розпочинається, але інтерес до проблем перинатальної психології дедалі більше зростає.

Життя особистості починається з внутрішньоутробного середовища, яке забезпечує їй материнський організм, надаючи широкий спектр впливових факторів, що зумовлюють все подальше ії життя. Сучасні можливості медицини та психології дозволяють досліджувати внутрішньоутробне життя плода, вивчати етапи його фізіологічного росту, формування органів та систем, психічного життя на різних стадіях розвитку, що суттєво змінило старі уявлення психологічної науки щодо внутрішньоутробного психічного життя, та відносно недавно визнала пренейта особистістю, яка формується.

Репродуктивний процес в цілому також викликає до себе багато питань та бажання розвинути нові кути дослідництва в галузі перинатальної психології. Впливовими факторами на репродуктивний процес можна вважати фізіологічні, соціальні та психологічні аспекти життя окремої особистості, особливо у період вагітності [3]. Дослідження психологічних аспектів гармонізації цього процесу являє собою сучасне актуальне середовище для дедалі глибшого занурювання та дослідження даного питання.

Проблемам жінок на різних етапах репродуктивного шляху, від зачаття до післяпологового періоду, присвячено досить багато робіт (Добряков І.В., Копил О.А., Баженова О.В., Бутман В.І., Філіппова Г.Г.). 
Кожний етап репродуктивного процесу заслуговує на увагу як науковців у галузі перинатальної психології, так i практичних психологів. До актуальних питань у дослідництві та вивчанні перинатальної сфери відносять психологію зачаття, психологію вагітності, психологію пологів, раннього постнатального періоду, впливу всіх періодів виношування, пологів на психічне здоров'я та життя особистості, кризові перинатальні питання, питання психологічних аспектів взаємодії вагітної та породіллі з лікарями в медичній системі, в акушерсько-гінекологічній галузі тощо.

На цьому не зупиняється актуальність розширення питань, пов'язаних із перинатальним простором. До доцільної зацікавленості сучасного наукового суспільства 3 питань перинатальної сфери Добряков І.В. відносить також психофізіологічні процеси репродуктивного періоду, сімейні взаємовідносини батька дитини, матері та самої дитини, триади системи [3]. Кожен етап репродуктивної системи має критичне значення у формуванні психічних особливостей особистості, тож для більш достовірних та доказових показників потрібно розширювати перинатальне коло знання. Етапи зачаття, вагітності та пологів - широке та багатоскладове питання, що спонукає до системного підходу й змушує розширити сферу дослідництва процесів зачаття, виношування, народження, раннього постнатального періоду до процесів вигодовування, виховання та повної сепарації дитини.

На думку провідних вчених в галузі перинатальної психології найбільш актуальними на сьогодні є наступні питання:

- психологічні фактори зачаття, вагітності, пологів та раннього дитинства;

- дослідження відношення жінки до зачаття, пологів в залежності від вихідного стану здоров'я, формування диади «мати-дитя», психічний розвиток пренейта та дитини;

- розробка та розширення методів психологічного дослідження 3 метою розв'язання психологічних задач у пренатальному, інтранатальному та постнатальному періодах;

- на етапах планування, зачаття, виношування вагітності, пологів та післяпологовому періоді створювання методів раннього психологічного втручання, направленого на оптимізацію течії даних періодів;

- вивчення та розробка методів психологічної допомоги сім'ям 3 перинатальною втратою, народженням хворої дитини;

- вирішення психологічних питань, що виникають в роботі з безпліддям, сурогатним материнством, екстракорпоральним заплідненням. 
Підвищення рівня свідомості пацієнтів, які потребують перинатальної допомоги, доведення їм користі терапевтичної дії $\epsilon$ важливими факторами своєчасного виявлення потреб у перинатальній психологічній допомозі та формуванні мотивації для iі отримання. Однією з актуальних проблем перинатальної психології є також підтримування тісної співпраці перинатальних психологів 3 акушерамигінекологами, неонатологами, неврологами та ін. [2].

Під час пренатального та перинатального періодів дитина перебуває у тісному зв'язку з матір'ю, що дає підстави робити висновки щодо впливу материнських процесів на формування психічного та фізіологічного здоров'я дитини. Порушення перебігу даних періодів можуть мати негативний вплив на генетичний потенціал, взаємодію 3 оточуючим середовищем майбутньої дитини. Внутрішньоутробний період відкладає глибокий відбиток на все подальше життя людини, насамперед, на іiі інтелектуальний та емоційний розвиток. Зокрема, дистрес вагітної жінки може привести до депресії, порушень психічного розвитку, агресії та ін., неадекватне ставлення матері до вагітності може спровокувати передчасні пологи, психопатологію дитини, схильність до девіантної поведінки. Отже, перинатальна психологія в сучасному суспільстві поступово переглядає уявлення щодо внутрішньоутробного розвитку та його ролі у формуванні феномену особистості, що суттєво впливає на розробку нових принципів у роботі з вагітними жінками, породіллями, сім'ями, що перебувають у перинатальному періоді [1].

Не менш важливим питанням у перинатальній психології $є$ вплив партнерських пологів на дитину та породіллю. Тема психологічної підтримки жінки у пологах $є$ неймовірно важливою та актуальною. Саме партнерські пологи, як своєчасна адекватна психологічна підтримка жінки, дозволяють знизити число оперативних посібників, кесаревих розтинів, аномалії пологової діяльності, дистресу плода у пологах, зменшують необхідність обезболювання та знижують об'єм крововтрати та гнойно-септичних ускладнень у післяпологовому періоді [4].

Розвиток та впровадження перинатального психологічного консультування, корекції та психотерапії, спрямованих на покращення психічного стану вагітних та породіль, гармонізацію відносин у сім'ях, які очікують на дитину та взаємодіють 3 новонародженим, є одним 3 пріоритетних питань перинатальної психології та держави [2].

Вирішення вище вказаних питань буде сприяти зниженню рівня патології у період вагітності та пологів, зменшенню кількості ново- 
народжених 3 нервово-психічними розладами, покращенню показників фізіологічного та психічного здоров'я нації в цілому.

\title{
Література:
}

1. Астахов В. М., Пузь І. В. Пренатальна і перенатальна психологія як складові частини психології розвитку. Проблема девіантного материнства: стан і шляхи вирішення. Медичні аспекти здоров'я жінки. 2011. № 1. С. 41-45.

2. Добряков I. В. Перинатальная психология - новий раздел клинической (медицинской) психологии. Електронний науковий журнал. 2012. № 5. URL: http://medpsy.ru/mprj/archiv_global/2012_5_16/ nomer/nomer27.php (дата звернення: 23.09.2020)

3. Добряков І. В. Перинатальна психологія. Пітер, 2010. 234 с.

4. Слободяник О. Я. Использование «Партнерских родов» для снижения акушерской патологии. Збірник наукових праџь інституту психологї імені Г. С. Костюка НАПН України. Психологічні науки. Київ, 2012. Том 5. Випуск 12. С. 162-168.

DOI https://doi.org/10.30525/978-9934-588-80-8-1.9

\section{ОСОБЛИВОСТІ ФОРМУВАННЯ ОСОБИСТОСТІ ВИПУСКНИКА ЕЛІТНОГО ТА ФАХОВОГО УНІВЕРСИТЕТУ}

\author{
Зеленько О. А. \\ кандидат медичних наук, \\ дочент кафедри загальної психологї \\ Київський національний університет імені Тараса Шевченка \\ м. Київ, Україна
}

Метою роботи є представлення погляду на формування особистості випускника елітного університету у порівнянні 3 особистістю випускника профільного фахового університету. Сучасна епоха характеризується переходом від доби технологічної революції до доби інформації. 3 другої половини XIX століття до кінця XX століття найбільш затребуваним продуктом системи вищої освіти був високо інформований та озброєний навичками фахівець. Університетська освіта полягала в першу чергу в тому, аби дати максимальну кількість знань та навчити користуватися ними для швидкого та ефективного вирішення задач, які ставилися перед фахівцем виробництвом та 